\title{
Chapter 6 \\ Formalised Boundaries Between \\ Polytechnics and Technical Universities: \\ Experiences from Portugal and Finland
}

\author{
Teresa Carvalho and Sara Diogo
}

\subsection{Introduction}

The structure of higher education systems has been under discussion since the turn of the millennium, especially regarding the future of binary or dual systems; i.e., systems constituted by two different types of higher education institutions.

Higher education institutions of a non-university type - dedicated to technical and professional training and applied research - are known under a range of labels. Well known examples include the German Fachhochschulen, the Hogescholen sector in the Netherlands, the Institutes of Technology in Ireland, the Polytechnic Institutions in Portugal and in Finland (Machado et al. 2008). This panoply of conventions is bewildering and raise confusion when adding the term technical universities into the discussion (Kyvik 2009). Nevertheless, there are differences in the terminology regarding professional higher education institutions worth exploring. Using the Weberian methodological tool of an ideal-type, one can define the traditional image or conception of polytechnics as referring to institutions that offer short-cycle professional and vocational programmes oriented to local and/or regional development and without a research mandate (Lepori and Kyvik 2010; Machado et al. 2008). These characteristics distinguished them from comprehensive universities that offered long-term programmes and developed scientific research, and from institutions such as KTH (Royal Institute of Technology in Stockholm), TUM (Technical University in Munich), MIT (Massachusetts Institute of Technology), EPFL (École Polytechnique Fédérale de Lausanne), TU Delft (Delft University of Technology) and TUT (Tampere University of Technology), which are considered to be technical universities because their focus is more on engineering education and they are more research intensive than polytechnics. In this context, one can also observe differences among technical universities, but

\footnotetext{
T. Carvalho $\cdot$ S. Diogo $(\bowtie)$

University of Aveiro, Aveiro, Portugal

e-mail: sara.diogo@ua.pt
} 
despite such variety, both types of higher education institutions - research-oriented technical universities and more technical-vocational institutions - had a complementary role within binary systems. However, what it means to be a technical university, a polytechnic or an UAS nowadays may differ substantially from historical conceptions of a technical university as seen in the first chapters of this book.

HEIS belonging to non-university sectors have in common that they were created to answer to the needs of human capital within an industrialised society. During the twentieth century, non-university institutions emerged in response to perceived failings of ivory tower comprehensive universities to respond to the competence needs of modern economies. In this context, they were expected to be more socially oriented offering professionally training and undertaking more applied research. The non-university sector is, in this sense, closer to the socially dominant notion of 'technical universities' as an organisational category. Like technical universities, non-university institutions are also more oriented to technological knowledge. As explained in Chap. 2, many technical universities had polytechnics as predecessors in its history.

The process through which non-university institutions may be transformed into 'technical universities' nowadays has been less researched. This chapter aims to shed light in this domain by using the case studies of Portugal and Finland. As such, this chapter focuses on the way the non-university sector has been evolving in Portugal and Finland, exploring its relationship with the university sector as well as its gradual positioning within the higher education field.

A prior challenge was the acknowledgment that the boundaries between comprehensive universities and other types of higher education institutions, such as polytechnics, Universities of Applied Sciences (UAS), and technical universities are difficult to define and highly dependent on national contexts. In fact, in binary systems technical universities are subject to both horizontal comparison - with comprehensive universities - and vertical comparison - with more professional institutions. However, the intensity of these comparisons varies as exemplified by the case studies presented here.

The way the continuation of binary systems has been questioned is mostly associated with the expansion and subsequent massification of the sector, the influence of the knowledge society, academic drift and professional drift, along with the increase in institutions' diversity and even pedagogical restructuring (e.g., the Bologna process). The pertinence of maintaining a binary or dual system, including institutions with different missions, has been raising national and institutional debates, with the OECD being called on to advice countries in this domain.

Portugal and Finland are two European, OECD member countries, with different historical, geographical, economic and cultural characteristics. In 2015, Finland occupied the 23rd position in the United Nations Human Development Report while Portugal ranked 41st (UNDP 2015). Both countries have a binary higher education system that in its initial phase consisted of polytechnics and universities, which has been submitted to similar environmental pressures, leading them to ask for OECD political advice. 
The reason why we focus on the OECD with respect to issues related to the continuity or discontinuity of the Portuguese and Finnish higher education binary systems and their operationalisation, and more specifically to the evolution and the current existence of polytechnics in these countries, stems from the political importance this organisation held and still holds for these governments in terms of legitimising their political action. Martens and Wolf (2009, p. 81) explain this relationship by stating that governments look at international organisations to pursue policy goals and also "because it was in their strategic interest to use the intergovernmental policy arena to manipulate the existing distribution of formal institutional competencies in their domestic political systems". Consequently governments gain leverage and legitimacy for their actions (Saarinen 2008; Kallo 2009; Kauko and Diogo 2012; Martens and Wolf 2009). This chapter assumes that the way higher education institutions are transformed, evolve and are socially conceptualised not only depends on national regulations, but also on the influence of supranational institutions.

Assuming that the OECD has a role as an epistemic community (Haas 1992), being able to frame the dominant notions of what higher education institutions and systems should be, it is relevant to understand which main underlying notions or concepts on the non-university sector frame OECD advices.

\subsection{Challenges to Dual Systems - What Distinguishes Professionally Oriented Higher Education Institutions?}

The topic of diversity has been widely discussed in the higher education literature (Birnbaum 1973; Trow 1995; Meek et al. 1996; Morphew and Huisman 2002; Wit 2007; Van Vught 2008; Huisman and van Vught 2009; Teichler 2014), assuming particular importance within the Bologna scope, since the "logic" of Bologna aspires to create "centrally organised diversity" (Marginson and Wende 2007, p. 48). Nevertheless, the implementation of such ideals created confusion and resistance in some higher education systems, such as the binary ones, which used to award more varied and longer degree programmes in the university component of the system.

The main concerns with this reform were related with the compatibility of the traditional degree structure - in which longer study cycles used to fall into the scope of comprehensive universities, and shorter ones, technical professionally oriented higher education degrees, were the domain of polytechnics, colleges or UAS - with the new two-tier cycle structure which stipulated that both academic and professionally oriented higher education institutions offer the bachelor and master programmes with the same length and applying the same nomenclature. In parallel, convergence and competition among European higher education institutions are emphasised by the European Commission. For example, discourses on the knowledge society have been used to promote European convergence on the grounds that economic competitiveness will be fuelled by research and development. Knowledge-society 
narratives (Santiago et al. 2008) legitimate the need to orient higher education institutions to society, research to innovation and teaching to employability. Thus, in the last three decades, and against this background, the binary divide has become increasingly blurred (Witte et al. 2008; Lepori and Kyvik 2010), giving room to several concerns, expectations and demands. These change dynamics transcend national boundaries, partly due to mimetic influence from internationally visible role models, and partly to similarities in the historical roots of polytechnic education and research across many western countries (Lepori and Kyvik 2010).

To a great extent, UASs and polytechnics changed in reference to comprehensive universities, and even to research-oriented universities. In their work on the research mission of higher education institutions outside the comprehensive university, Kyvik and Lepori (2010) referred to Burgess (1972) to describe the tendency of non-university higher education institutions to orient their activities in ways that bring them closer to the university template; namely, the development of research, designating this phenomenon as academic drift. The authors consider that this is, in fact, a special case of academic drift, which can be even labelled as research drift (Kyvik and Lepori 2010). On this, Harwood (2010) explains that the practice underlying academic drift - not only in higher education - is the process through which knowledge "(...) gradually loses close ties to practice while becoming more tightly integrated with one or other body of scientific knowledge". This explains why the same phenomenon in the United States is labelled "mission creep" (Badley 1998). In Norway, for example, university colleges had increasingly emphasised research as an important faculty task in addition to teaching (Kyvik and Skodvin 2003) ${ }^{1}$. Furthermore, it is also possible that the development of research in non-university higher education institutions is a result of the need these institutions felt to improve professional education and professional practice in occupations for which universities do not train people (Kyvik and Skodvin 2003) - similarly to the need of strengthening polytechnics' roles as regional knowledge providers (Heggen et al. 2010; Jongbloed 2010). Simultaneously, the introduction of master's degrees in polytechnics/UAS (due to the Bologna degree restructuration) implied that the curricula of these programmes required staff with research experience mainly, as this was required by national accreditation agencies (Lepori and Kyvik 2010). In parallel, professional institutions also become more prone to behave like universities since teachers in professional higher education institutions mainly graduated in universities and therefore carried to this subsystem the university culture they acquired in the past, imposing an academic drift based on normative isomorphism (Cardoso et al. 2011; Diogo et al. 2015; Kyvik and Lepori 2010; March and Olsen 1983).

These changes in research and teaching led to increasing convergence in higher education systems with the traditional boundaries between basic and applied research gradually disappearing (Horta et al. 2008; Santiago et al. 2008). In parallel, the inverse process of professional drift also emerged in the university subsystem.

\footnotetext{
${ }^{1}$ At the present, there are hardly any of these institutions left in Norway anymore - most of these have either been upgraded to university status or merged with a university.
} 
This phenomenon is very much fuelled by the discourses on the knowledge society and the national innovation systems (Lundvall 2007), encouraging a stronger relation between universities and society. In this context, the production of knowledge is more associated with "applied" research, and teaching is also assumed to be more oriented to employability, also leading to professional drift in universities (Machado et al. 2008).

A visible sign of professional drift in the university subsystem is the way it has been shaping training programmes in order to comply with market needs and to increase graduates' employability (Harwood 2010; Morphew and Huisman 2002). Another relevant sign of this is the emergence and development of different forms of producing knowledge, other than basic or applied science.

It is, however, relevant to highlight that binary systems include institutions with different reputations (Scott 1995); usually universities tend to have a high symbolic status within the system (Badley 1998). As pointed out by Amaral and Magalhães (2005, p. 126): "diversification via a binary system is tainted by a political suspicion: the elitism implicit within the university subsystem". Adopting the sociological institutionalism perspective, it is possible to sustain that the search for stability, legitimacy and social prestige partly explains the academic drift in professional institutions (Oliver 1991; Cardoso et al. 2011; Magalhães 2004).

Within this context, stakeholders with divergent interests (namely non-university institutions and comprehensive university leaders) start pressuring national governments to promote changes in the system in different directions. Faced with these pressures, national governments started looking for external support in international organisations (such as the OECD) to advice on the best way to reform the structure of higher education systems.

Even if the OECD has no legally binding mandates in terms of educational policy of each member-state (Martens and Wolf 2009), it has the symbolic power to envisage polytechnics and UAS and recommend their role in binary systems. In this sense, the OECD can be interpreted as having a relevant role in the reconfiguration of national non-university institutions.

\subsection{The Portuguese and Finish Higher Education Professional Subsystems}

In Portugal, the professional higher education sector was formally established in 1973 through the Reform Act passed by the National Assembly (DL 402/73), under the 'Veiga Simão Reform', but due to the 1974 revolution, the process of expansion and development of the sector was disrupted. It was only in 1977 that the DL 427B/77 (14th October) instituted the polytechnic higher education subsystem as aiming to train expert technicians and professionals of education at an intermediate level of higher education. From 1977 to 1981 there was a clarification of the strategic guiding principles defining the objectives of the polytechnic subsystem, namely 
bringing it closer to the economic and social needs of the country (Amaral et al. 2002). The OECD reports and recommendations, as well as their focus on the 'human capital' theory, helped to guide the strategic planning of Portuguese higher education (ibidem). The link with economic and regional development was reinforced through the agreement on specific objectives concerning the institutional mission of public polytechnics, which was meant to be different from "the more conceptual and theoretical characteristics" of universities (Magalhães 2004, p. 303). As such, Portuguese polytechnics, which have their origins in the former vocational education Institutes of Industry and Commerce, were expected to develop nontraditional research areas, quite differently from many of their European counterparts, which were not supposed to engage in research (Lepori and Kyvik 2010). In fact, since their creation, even if in moderate terms, polytechnics in Portugal were expected to perform "guided research" for the needs of national industry and closely align their education with the needs of the national labour market.

The development of the vocational subsystem was also strongly motivated by another attractive, political objective; namely to increase the chances of Portugal becoming a European Union member. The priorities were altered to match the performance of other European countries, to act strategically in terms of quantity, quality and access procedures (Amaral et al. 2002). The 1980s and 1990s were the "golden years" for polytechnics in Portugal. Public polytechnics have concentrated their enrolments in Engineering, Management and Business Administration (within the area of Social Sciences), Education/Teacher Training, Health and Social Protection and Agriculture, which corresponded roughly to the recommendations of the World Bank (Amaral and Magalhães 2007 p. 70). The literature also confirms that public higher education institutions, universities first and then polytechnics, tend to be the first choice of the majority of Portuguese students (Pedrosa et al. 2017).

Despite the existence of distinct types of higher education institutions in Portugal, universities continue to offer a higher number of vacancies and there is a higher number of enrolments in this subsystem. Even if there are differences in the total number of enrolled students each year, on average students enrolled in the polytechnic subsystem in Portugal represent around $40 \%$ of the total number of enrolled students in higher education (DGEEC 2017). Thus, within the public sector, consolidating the polytechnic subsystem took far longer than it did for the university subsystem (Almeida and Vieira 2011).

Although almost two decades later than Portugal, it was the belief in investing in human capital as the ultimate and indisputable spearhead of national progress that provided the Finnish higher education system with legitimacy and willingness to advance educational visions, proposing new concepts of youth and higher vocational education, and to expand higher and adult education (Rinne 2004, p. 98). Curiously, by the early 1990s, Finland was one of the few countries in the European Union with a uniform higher education system, consisting of universities only. Thus, the first polytechnics in Finland emerged with the wishes of the Finnish government to transform the country into a knowledge society. In order for this to happen, it was necessary to raise the knowledge and skill levels of the population by doubling higher education enrolments (Välimaa and Neuvonen-Rauhala 2008). As 
it was visible that universities could not expand their offerings without endangering the quality of education and research, there was the need to find an attractive alternative at the higher education level and to improve students' chances of finding a higher education study place. Also during the expansion period of the Finnish higher education system, the provision of equal educational opportunities became one of the most important objectives pursued by governments (Välimaa 2004). Similar to Portugal, pressures emerging from an increasingly massified system allowed for the diversification of Finnish higher education and subsequent creation of a nonuniversity sector. Simultaneously, the development of modern technology and its rapid introduction into Finnish working life demanded the need for better-qualified people in the labour market. Indeed, this also contributed to the emergence of pressures for status competition of higher education degrees among professions and institutions as well as from labour market allocation and recruiting needs (Rinne 2004, p. 98).

Another important factor contributing to the establishment of the Finnish nonuniversity sector was the Europeanisation journey. Especially after 1995, when Finland joined the European Union, and later on with the implementation of the Bologna process and subsequent convergence movements of European higher education systems, there were political pressures from the European Union for a renewed role, status and function of higher education in society.

One of the expectations with the Bologna reforms in the Finnish polytechnics was to provide their students an opportunity to deepen their professional competencies as well as to create opportunities for polytechnics to develop their activities as labour market-oriented higher education institutions. Another objective was to differentiate between polytechnic and university Master's degrees and to promote internationalisation in Finnish polytechnics. Nevertheless, the comparability of degrees and their prestige and status in relation to university degrees was found to be somewhat poor (FINHEEC 2012). Moreover, as in Portugal, the fact that both types of higher education institutions confer both bachelor and master degrees with the same degree titles does not help to differentiate both subsystems.

The establishment of the non-university sector was thus part of an extensive reform of post-secondary education, which consisted in merging around 215 existing technical and business colleges, and other secondary level institutions to form 32 polytechnics (Välimaa and Neuvonen-Rauhala 2008), also abbreviated to AMKs (ammattikorkeakoulut in Finnish). Similar to Portugal, the main supporters of the foundation of AMKs were the representatives of provinces and provincial institutions who saw the status of their upper secondary education institutions upgraded. On the side of universities, there were some mixed feelings about the new sector of higher education, as universities feared that it would shrink the higher education budget (Välimaa and Neuvonen-Rauhala 2008, p. 80).

In the beginning of the new millennium, Finnish polytechnic institutions began to be assumed and legally designated (Law 932/2014) as Universities of Applied Sciences (UAS). At present, most UAS are regional institutions with students being encouraged to make use of multidisciplinarity, namely by establishing their own business and combining enterprise education in many forms (Hölttä and Malkki 
2000). Student selection in polytechnics is mostly based on secondary school achievement, work experience and in many cases, entrance examinations.

Finland has currently 14 universities and 24 universities of applied sciences (OKM 2016), while Portugal has 38 universities (14 public universities and 24 private); and 65 polytechnics (20 public polytechnics and 45 private) (Pedrosa et al. 2017, p. 65). The largest fields of study in Finnish UAS are engineering and transport, administration and commerce, social services and health care, information technology, and telecommunications (Official Statistics of Finland, OFS 2018). Finnish UAS account for a large share of national student enrolments, although still lower than universities (OFS 2016).

In the last two decades, the pertinence of maintaining a binary or dual system of higher education institutions has been questioned due to the increasingly blurred mission of both types of institutions, as mentioned before.

To a great extent, the discussion on the blurring of the institutional mission of HEIs, and the operationalisation of the binary divide in both countries provided Portuguese and Finnish governments with legitimacy to enforce change recommended in international forums. The OECD was then called on to advise countries in this domain, being relevant to analyse if and how the non-university institutions can evolve to become closer to the category of 'technical university'.

\subsection{Methods and Data}

Bearing in mind the binary organisation of both higher education systems, their development and the diversity among HEIs, a system level perspective is applied to understand how institutions have been re-conceptualising their role/mission in the present knowledge society.

Therefore, the next section discusses these views through the lenses of the OECD and through the voices of Finnish and Portuguese practitioners.

Analyses of OECD reports for Portugal and Finland were complemented with the discourses of 26 key actors interviewed at the national and institutional levels during the years 2011 and 2012. At the national level, 12 key actors (policy makers and former higher education ministers) were interviewed: six in Portugal and six in Finland. At the institutional level, the focus was on the institutional interviews carried out in the professional subsystem, having interviewed seven people with different roles (top-management actors and academics with management duties) in one Portuguese polytechnic and in one Finnish UAS. Both OECD reports and interviews were submitted to content analysis (Bardin 2010). Based on the theoretical framework and in the empirical data, three main dimensions of analysis were identified; namely: maintaining the binary structure; operationalizing the divide and new roles for higher professional education institutions. A summary of this content analysis can be found in the Appendix (Table 6.1). 


\subsection{Challenges of Dual Systems: A Single Binary Higher Education Model?}

Diversity of institutional types is usually presented as a positive characteristic of higher education systems (Morphew and Huisman 2002) since it allows for teaching a large number of students without increasing the costs of education, while simultaneously offering distinct training to students more suitable to perform specific jobs (Guri-Rosenblit et al. 2007). This diversity also introduces more complexity and hierarchisation in the systems. Since comprehensive universities have been considered as the prototype of the 'University', the way other institutions may be reconfigured is expected to be by reference to it. This is especially true for Portugal where the existence of comprehensive universities since the XIII century give them a strong legitimation in the system.

OECD reports on the Portuguese and Finnish higher education systems diagnosed the existent systems, proposed a specific model for both and provided recommendations for the operationalisation of each country's higher education system. The following section compares these recommendations that are synthesised in Table 6.1.

Both panels agreed on the importance of maintaining a diversified binary higher education system in the two countries, visible in expressions such as: "The binary system should be maintained and strengthened" (OECD 2007, p. 55) and "Instead of blurring the boundaries between universities and polytechnics the vocational side of the tertiary system should be strengthened" (OECD 2009, p. 36). This common recommendation prescribed to the structure of both Portuguese and Finnish higher education systems suggests that the OECD recommended the continuity of the binary system in both countries. However, when analysing the way the OECD suggests countries to operationalise the divide, different models emerge, translating to different ideal types of higher professional education in each country.

While in Portugal the tendency was to recommend a diverse system, for Finland the OECD suggested a stronger role in the UAS research mission. Nevertheless, the team who assessed the Portuguese higher education system was more straightforward than the Finnish review team. In fact, the report on the Finnish higher education system is subtler, providing some leeway and room for other forms of differentiation than "simple duality". Actually, and especially regarding Portuguese higher education, the OECD offered a substantial amount of suggestions to differentiate both subsystems, which mostly related to: the type and nature of the degrees each type of higher education institution could award; governance structures; internal cultures and management practices; research vs. teaching functions; funding mechanisms; staff qualifications; etc. In sum, all the aspects covered in the OECD reports advice measures to differentiate universities and polytechnics. To a great extent, the operationalisation of the divide between polytechnics and universities in Portugal is presented in a way that reinforces the polytechnics' position in society and, in this sense, also reinforces its less prestigious position in the system. In this sense, the OECD reinforces the traditional position of polytechnics enabling its 
evolution to 'technical universities'. Actually, polytechnics and technical universities are classified as distinct institutions. The first are expected to be devoted to vocational training and restrict the research they develop to 'applied research' while the second is sustained in the idea of developing technological knowledge and produce advance technological knowledge. The traditional ideal type of a polytechnic is clearly reinforced in this report both in relation to teaching and to research. In the case of Portugal the OECD turns to the perspective that polytechnics have a fundamental role in improving the qualifications of the population to support economic competitiveness. "They [polytechnics] need to return to their core mission of developing employable graduates with practical know-how, underpinned by analytical and problem-solving abilities" (OECD 2007, p. 78). Nevertheless, with respect to Finland, research specific roles are defined as aligned with the new codes of knowledge production: "the polytechnic role in the research space should not encroach on the university role but should be complementary to it, by focusing rather on technology transfer and development" (OECD 2007, p. 12). In this context, the recommendations are more aligned with the possibility of non-university institutions evolving into technical universities.

At this stage, it is important to highlight that these different OECD visions may reflect not only the different governments' wishes, but also the different national realities. By the time the OECD revisions were conducted, Portugal was in a deep financial crisis. Maintaining different study options for a diversified student population, while following the "European Bologna model" went in line with the needs and challenges the country faced, while simultaneously avoiding increased expenses with the intensification of research in polytechnics if a unitary system was recommended.

Suggestions for Portugal are presented in the spirit of protecting the diversity of the system by limiting the capacity of universities to engage in professional drift (OECD 2007, p. 49), and the polytechnic tendency to be involved in academic drift (OECD 2007, p. 12).

Recommendations for specific legislation, clearly dividing the two subsystems, were also advised by the OECD:

It is recommended that the government should introduce comprehensive university and polytechnic legislation in which (...) the different roles of universities and polytechnics are specified. (...) ( 2007 p. 55).

As a result of these recommendations, the Portuguese government passed legislation (DL 74/2006 and Law 62/2007) reassuring the binary divide of the system, even if some of the polytechnics' aspirations were taken into account. Examples of accepted polytechnics' ambitions were the development of master's programmes (forcibly professional in polytechnics and scientific and integrated masters in universities); an increase of staff holding PhDs; or even the creation of consortia and not mergers. Interviewees perceive this difference as a positive step towards the increase of the prestige of professional higher education institutions, considering that the legislation (Law 62/2007) demanded higher qualifications for polytechnics' staff and allowed for the creation of consortia and partnerships, which is likely to 
have an impact on the participation in national and international networks, as mentioned by one interviewee:

It [Law 62/2007] helped to consolidate the image of polytechnics, once it helps to dilute their old problem of low quality perceptions (PMM).

This statement shows that institutional actors working in Portuguese polytechnics faced the stigma of lower prestige of these institutions, making them keener to defend a unitary system.

The differences between the two subsystems were also strengthened by the type of qualifications each one could offer, since the capacity to offer $\mathrm{PhD}$ programmes was conceded only to universities (Decree-Law 43/2014).

The suggestions to operationalise the system divide in Finland are presented in an opposite perspective to the Portuguese one. The main recommendations to institutionalise the binary framework are based on the institutionalisation of new roles for higher professional education institutions in Finland.

On this topic, Finnish UAS interviewees (contrary to their Portuguese counterparts) did not welcome the Bologna reforms; namely the reduction of the bachelors' length:

Especially in the case of the School of Technology and their engineering programmes: they simply don't understand how you can guarantee the competences of the engineers in three years (...). The feeling I got, because in Finland we have quite strong associations of engineers and they have been consulted quite heavily, is that in order to guarantee the skills and the beliefs/attitudes to act as an engineer, you cannot do it in three years! (FPL).

The OECD also acknowledges the pertinence of having differentiation in Finland, but based on compliance; i.e. a unitary system which is more aligned with the conceptualisation of traditional universities. Bearing this in mind, it can be said that the OECD recommendations support more a potential transformation of non-university institutions into technical universities. The defence of the maintenance of a binary system is based on the assumption that UAS can be improved. This progress may be aligned with their conceptualisation as technical universities.

The dual structure of the Finnish tertiary system should be upheld and the profile of the two sectors should be developed further according to the principle "different but equal" (OECD 2009, p. 35).

While in Portugal, higher professional education institutions were recommended to focus mainly on professionally oriented teaching and were forbidden to award doctorate degrees, in Finland, they were incited to diversify their teaching target and offer PhD programmes.

(...) the possibility that polytechnics could be accredited to offer doctorates, as well as postgraduate professional doctorates, in areas of acknowledged expertise, under appropriate conditions of quality assurance, and attached to an appropriate graduate school (OECD 2009, p. 51).

Simultaneously, higher professional education institutions were also stimulated to diversify their research mission and to include a new research paradigm (OECD 2009, p. 92). The recommendations related to research activities can, on the one 
hand, be assumed as examples of academic drift in the higher professional education subsystem. However, on the other hand, this specialisation of Finnish UAS towards applied research, different from traditional universities, maintains the binary divide, respecting each type of organisational field mission.

Polytechnics should develop a research strategy, (...) which would be likely to include, inter alia: inclusion of research in under- and postgraduate programmes and research training strategy; research contract generation priorities; essential items of internal research organisation and infrastructure; research collaboration priorities; (...) (OECD 2009, p. 52).

The dual recommendations for Portugal and Finland resulted in different national solutions for a binary structure, also resulting in different ideal types of professionally oriented institutions. In Finland, although the new legislation on this matter only came in 2014 (Law 932/2014, Universities of Applied Sciences Act), polytechnic institutions began to be assumed as, and to call themselves, Universities of Applied Sciences (UAS) during the implementation of the Bologna process.

The new designation seems to be institutionalised in the Finnish higher education system since not only the ministry assumes it, but also the institutional actors defend its adequacy. In fact, institutional actors working in this subsystem (in 2011) adamantly refused to be called "polytechnics": "The term UAS describes better what we do now than the term polytechnics" (FS).

In Portugal, since the DL 74/2006 until the present day, none of the polytechnics was upgraded to universities, their nomenclature is still the same, they are still called polytechnics and not UAS, and only now discussions are beginning to assess the possibilities to confer PhDs. According to the latest national legislation, Portuguese polytechnic institutes are "(...) high-level institutions dedicated to the creation, transmission and dissemination of culture and professionally-orientated knowledge through study, teaching, guided research and experimental development" (Law 62/2007 §7, $1^{\circ}$ ).

Different national realties, cultural factors and political traditions can explain this difference of position and acceptance. It is widely acknowledged that even though Finnish UAS are younger higher education institutions than their Portuguese counterparts, they do have a higher status and a more consolidated image than Portuguese polytechnics, also due to "high-quality, well-trained teachers, with strong academic qualifications and master's degrees" (Sahlberg 2011, p. 9). In fact, as it is perceptible in the Finnish OECD (2009, p. 114) report, this image of quality is "discernible to frequent visitors". Despite both OECD teams agreeing to maintain the binary divide, the paths to carry out this aim were distinct for the two countries, resulting in defining distinct non-university higher education institutions with two different ideal types in the two countries. While in Portugal the ideal type is more aligned with polytechnics' historical mission, in Finland their aims and objectives are more similar to those characterising comprehensive or even technical universities.

Different hypotheses can be formulated to explain these different recommendations. One is related with the economic realities of the two countries. Since Finland has a more stable economic situation, it could be assumed that the country has more 
resources to distribute more evenly within the system. Finland is one of the leading countries in Europe in terms of education and technological advancement, making the country closer to become a truly knowledge society. Furthermore, the higher levels of qualification of the population indicate that the need for diverse institutions to improve student enrolment is less relevant. An opposite situation is acknowledged by Portuguese actors who see polytechnic institutions as providers of higher qualifications with lower costs.

(...) the effort one needs to do (...) will be smaller if the professional qualification programmes will be implemented on the polytechnic sector (Ps).

On the other hand, as mentioned previously, one cannot neglect the hypothesis that the OECD experts are also influenced by national governments in their proposals. It is possible that the different suggestions result from distinct national pressures of each country to organise their higher education systems.

The analysis of OECD reports allows for the conclusion that, for the specific case of the systems' structures, and, more specifically, for the hypothesis of nonuniversity institutions turn into technical universities in the near future, one cannot talk about convergence policies nor about isomorphic behaviour between different national governments based on international organisations' similar recommendations. Although the OECD states that the polytechnic mission has to develop and offer teaching and research activities more oriented to the economic and social tissue, the scope of their action is quite different for the two national contexts, which reinforces the idea that boundaries between universities and polytechnics are hard to define. Even in the Portuguese case, where the polytechnic is historically more consolidated, the general perception of Portuguese interviewees about the binary divide and role of polytechnics in the country still seems to be "unproductive". Most of them mentioned that despite all legislative efforts made to differentiate both subsystems, in practice, it is still difficult to know:

where the polytechnic ends and the university starts. With or without Bologna, the system will continue to be binary and it will continue to not make sense. I mean, polytechnics will progress towards becoming universities and universities will be closer to the labour markets and offering more vocational programmes that would be 'polytechnics' property' (PMM).

Not very different from the Portuguese scenario, Finnish interviewees believe that both recent pieces of legislation - the New Universities Act and the Universities of Applied Sciences Act "allow for increasingly more academic research, turning universities closer to UAS, through the third mission." (FPTM).

It is also interesting that regardless of nationality, interviewees belonging to the university subsystem still feel a kind of discomfort with the idea of being compared with more professionally-oriented institutions. They still position themselves - and their work - in a higher position (with a higher status) than those working in UAS.

In Finland there still exists this dual system, research universities and UAS, and there is tension, you can call it competition, but is also competition for respect, for the status. I don't know if we compete from the students' point of view, because both systems have quite a lot of applicants... I think it is more about the status and the staff (FPTM). 
Taking the fact that the OECD recommends to improve the status of UAS, it can be said that the possibility to upgrade non-university institutions to technical universities depends on national contexts - with countries with more universal higher education systems and more economically developed having a higher probability of moving in this direction.

Quite different is the discourse of system actors belonging to the organisational field of UAS and polytechnics, as they position the institutions and their role as equal to comprehensive universities: the same quality, the same level of hierarchy and demands. In Portugal, this was particularly evidenced from system level actors, which reflects the lack of compliance when compared to Finnish interviewees:

The polytechnic won with Bologna because it gained the possibility of conferring masters degrees. (...) Therefore, polytechnics have been re-qualified because the profile of an institution is also defined by the top of degrees it can confer and now, with Bologna, they can create and assign 2nd cycle programmes, though not yet 3rd cycle programmes (Ps).

Nevertheless, and in line with what institutional actors feel about the maintenance of the binary system, "it doesn't seem to me that polytechnics used this [the possibility of conferring 2nd cycles] in Portugal to be really different in their mission. I don't see great evolution" (Ps).

In some cases, and especially in Finnish UAS, interviewees were quite critical about traditional universities, mentioning that UAS are innovative and in line with the demands of the present knowledge society.

There are people who think that we are threat for the research universities in the sense that historically Finland has been for the pure objective research and truth and now we are here with applied research. At the same time, research universities are supposed to have more links to the real life. So, actually we are even a bit afraid that the idea of the objective truth might disappear from the Finnish higher education system (FPTM).

These developments represent the types of tensions/challenges that have emerged in both higher education systems and higher education institutions when trying to maintain the binary organisation and diversity of missions and profiles, while simultaneously competing for economic and social relevance and academic practices.

\subsection{Conclusions}

Binary systems were created to accommodate a high demand of students in higher education, to promote more diverse and inclusive training and to foster economic and social regional development. Within this system, diverse and complementary higher education institutions were created with distinct roles and missions. Historically, some of these institutions, specifically polytechnic institutions, were transformed into technical universities. In the last three or four decades, a public and political debate emerged on the pertinence of maintaining this organisation. To a 
great extent, the doubts about the usefulness of maintaining these systems resulted from the blurring of institutional missions among higher education institutions as a result of pressures associated with such diverse factors as the massification of the sector, the narratives on knowledge society, academic drift and professional drift, and the pedagogical restructuring (e.g., the Bologna process).

Professional drift and academic drift make polytechnics and comprehensive universities more alike, questioning their specific and complementary roles. Simultaneously, the stratification of binary systems induces key actors in these institutions to strive for different solutions. While in polytechnics and UAS actors tend to support a unitary system, in comprehensive universities the tendency is to argue for the reinforcement of the divide. The way binary systems may change is especially relevant since it may induce an increase in the number of technical universities in the unitary systems. Faced with different pressures, national governments resort to experts' advice through international organisations such as the OECD.

This chapter argues that the way higher education institutions are conceptualised and reconfigured is dependent on the national context. There is some tension between higher education key actors aims' to turn the systems more unified and the OECD reports that recommend different paths for the binary systems.

Reflecting on the extent to which diverse systems can evolve in such a way that allow non-university institutions to evolve to a technical university model, this chapter concludes that this possibility is highly dependent on the context. Based on the analysis of OECD recommendations and on the key actors discourses one can say that there is a higher tendency for non-university institutions to be perceived as evolving to technical universities in countries with higher levels of economic and technological development and with universal higher education systems. In countries with less economic development and with massified systems, as the Portuguese one, this tendency is less evidenced. What seems to be in place is a reinforcement of the distinctiveness of polytechnics, reinforcing its role as improving human capital.

The intent to create polytechnic institutions in Portugal and in Finland was aligned with the aim to increase students' participation in higher education and to promote economic regional development. Polytechnic institutions were framed by an ideal type that characterised them as oriented to short-term professional training and to applied research able to serve as an instrument for economic development.

Regarding common challenges such as professional drift and academic drift, the knowledge society and pedagogical restructuring, OECD recommendations propose a continuity for the traditional ideal type in Portugal and a discontinuity in Finland. In the first case, the government is advised to keep a different mission in polytechnics centred in specific training programs (and even specific students), and in research with a more applied orientation. In Finland, the recommendations frame UAS in an ideal type characterised by training programs similar to those in comprehensive universities (such as the $\mathrm{PhD}$ programs) and on research activities that are expected to be reinforced (even if aligned with the new modes of knowledge 
production), being even incorporated within training programs. The reasons for these distinct recommendations may lay in the different levels of development in the two countries. The lower economic development and qualification levels of the Portuguese population seem to influence the need to maintain the initial purposes of polytechnic institutions.

In Portugal the dominant construct of the OECD and national legislation on polytechnics' roles follow the traditional route based on a path of continuity. At the same time, in Finland the dominant construct can be defined as aligned with a path of discontinuity with the roles attributed to UAS representing a rupture with the traditional conceptions of its specific teaching and research activities, making it closer to the transformation in technical universities and also to knowledge society objectives and discourses.

While in Portugal this historical evolution is framed by a trend to maintain their traditional ideal type, in Finland polytechnic institutions have evolved into UAS, making them closer to technical universities, as there is a greater emphasis in research and especially in the teaching-research nexus. The fact that the training expansion in polytechnic institutions in Portugal has been more concentrated on educational and social sciences - and less on technical and research constructs may justify their non-evolution to technical universities. The analysis of OECD reports reveals that the boundaries between comprehensive universities and professional higher education institutions, such as polytechnics, UAS, and technical universities are difficult to define and highly dependent on national contexts. Nevertheless, the evolution from polytechnics to UAS and to technical universities seems to be based on the level of commitment to research and on high-level training programmes, such as $\mathrm{PhD}$ degrees.

The OECD has no single cognitive construct on what a polytechnic, a UAS, or a technical university represents within a binary system, its recommendations being highly influenced by the national contexts. Despite the similar pressures binary systems are facing, it seems that a traditional ideal type of more professionally-oriented higher education institutions, these being polytechnics, UAS, or technical universities, is still interpreted as relevant in crisis environments, and environments of growing uncertainty, as that faced recently by Portugal. Nevertheless, the reinforcement of the traditional ideal type may strengthen the system stratification and, in this sense, may increase pressures of polytechnics' institutional actors to eliminate the divide as expressed by interviewees' discourses. More studies are needed to analyse the role of different actors and power negotiations to consolidate a single ideal type for professionally oriented universities.

This work was financially supported by POCI-01-0145-FEDER-029427 funded by FEDER, through COMPETE2020 - Programa Operacional Competitividade e Internacionalização (POCI), and by national funds $(\mathrm{OE})$, through FCT/MCTES (Portugal). 


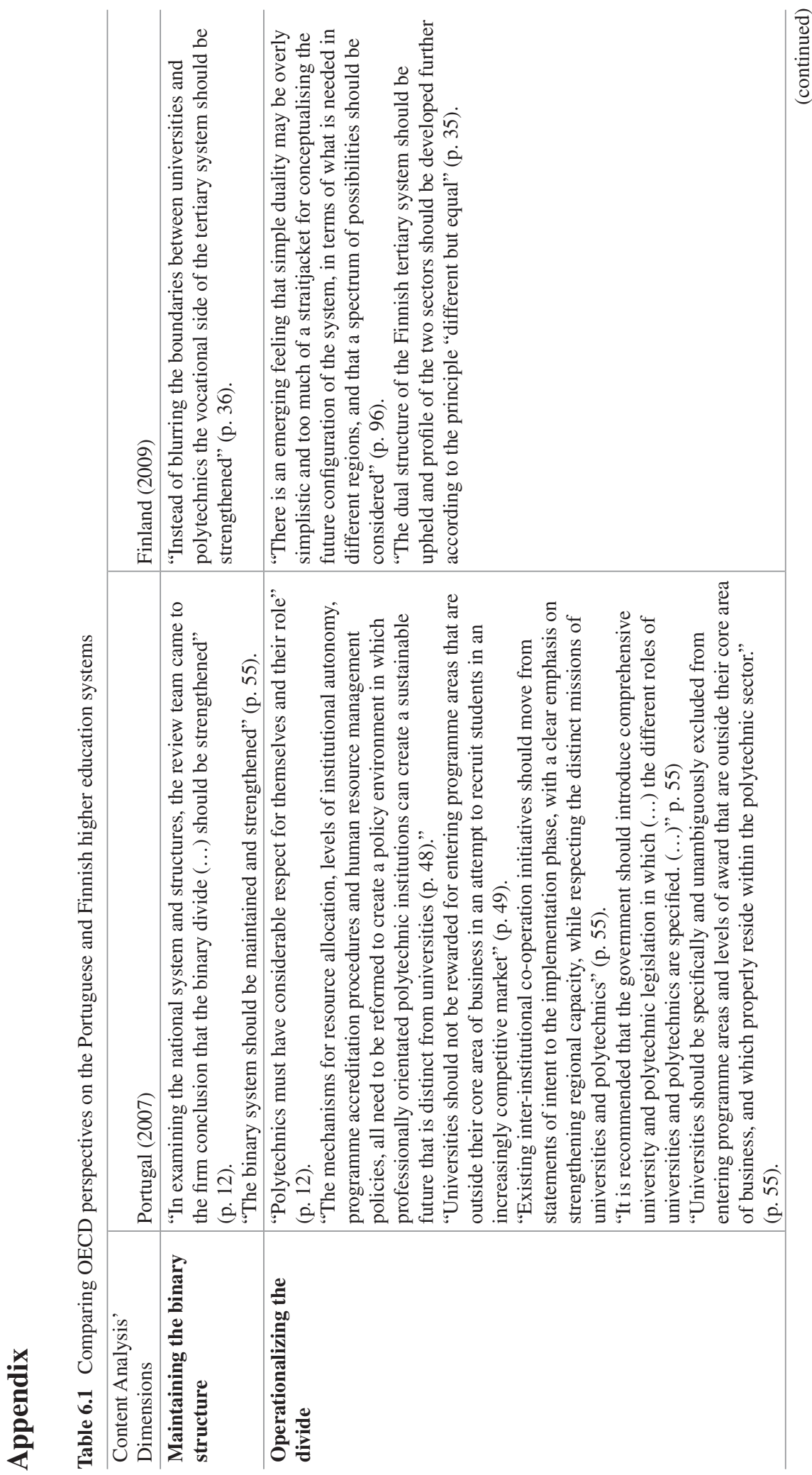




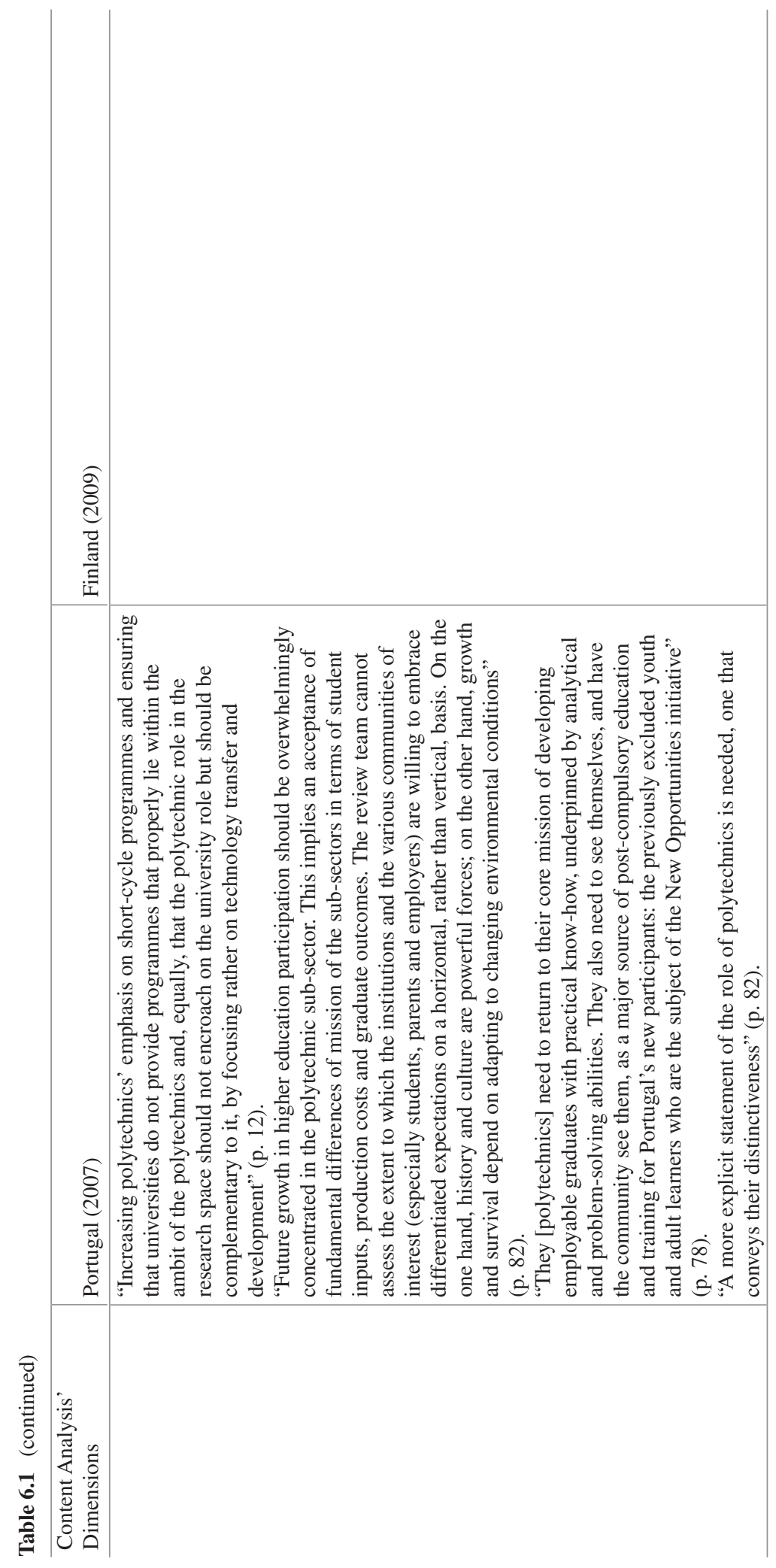




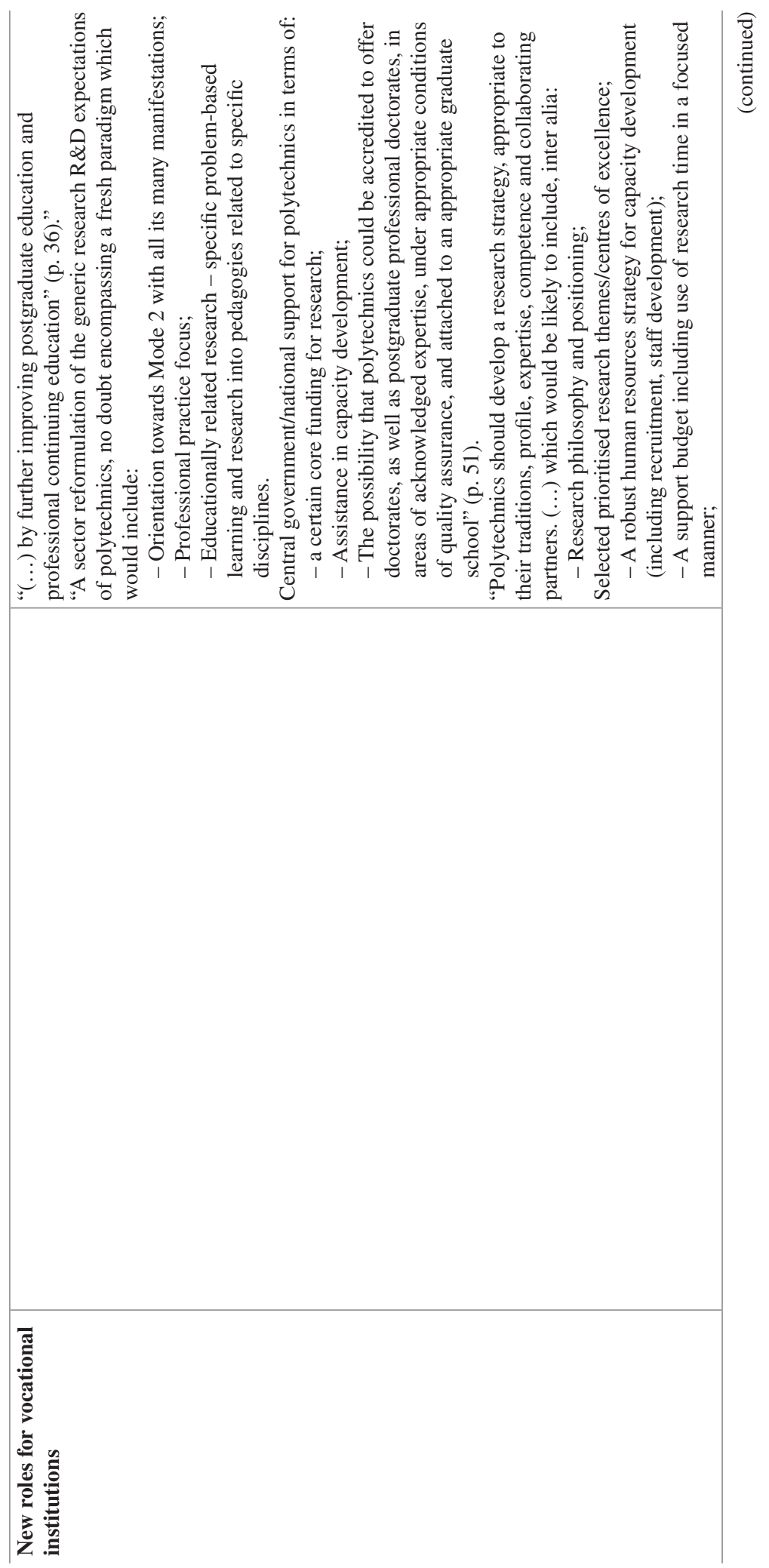




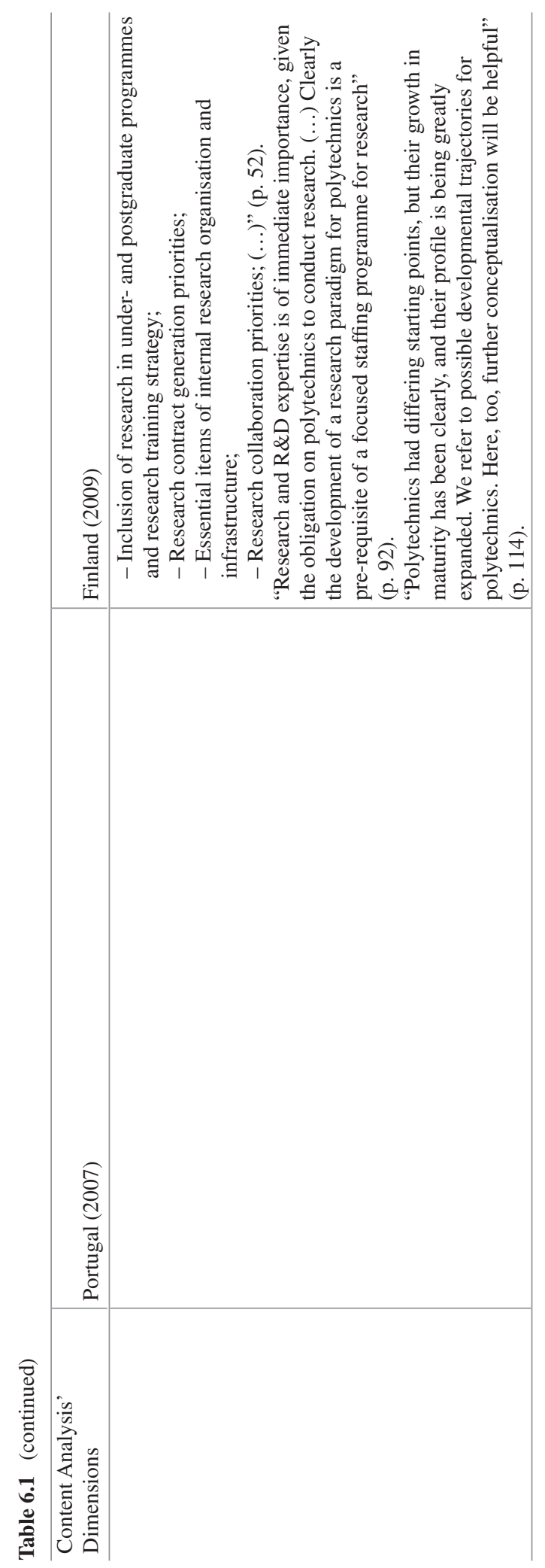




\section{References}

Almeida, A. \& Vieira, M. (2011). From university to diversity: The making of Portuguese higher education. In G. Neave, \& A. Amaral, (Eds.), Higher education in Portugal 1974-2009: A nation, a generation (pp. 137-159). Dordrecht: Springer.

Amaral, A., Jones, G. A., \& Karseth, B. (2002). Governing higher education: Comparing national perspectives. In A. Amaral, G. A. Jones, \& B. Karseth (Eds.), Governing higher education: National perspectives on institutional governance (pp. 279-298). Dordrecht: Springer.

Amaral, A., \& Magalhães, A. (2005). Implementation of higher education policies: A Portuguese example. In Å. Gornitzka, M. Kogan, \& A. Amaral (Eds.), Reform and change in higher education (pp. 117-134). Dordrecht: Springer.

Amaral, A., \& Magalhães, A. (2007). Market competition, public good and institutional governance: Analyses of Portugal's experience. Higher Education Management \& Policy, 19(1), 63-76.

Badley, G. (1998). Making a case for educational development in times of drift and shift. Quality Assurance in Education, 6(2), 64-73.

Bardin, L. (2010). Análise de conteúdo. (1977). Lisboa (Portugal): Edições, 70, 225.

Birnbaum, R. (1973). Maintaining diversity in higher education. San Francisco: Jossey-Bass.

Burgess, T. (1972). The shape of higher education. London: Cornmarket Press.

Cardoso, S., Carvalho, T., \& Santiago, R. (2011). From students to consumers: Reflections on the marketisation of Portuguese higher education. European Journal of Education, 46(2), 271-284.

Decree-Law No. 74/2006, of 24 March. Graus académicos e diplomas do ensino superior [Higher Education Academic Degrees and Diplomas]. In Diário da República.

DGEEC. (2017). Instituições de Ensino Superior Portuguesas [Portuguese Higher Education Institutions]. Retrieved from http://www.dges.mctes.pt/DGES/pt/Reconhecimento/ NARICENIC/Ensino+Superior/Institui\%C3\%A7\%C3\%B5es+de+Ensino+Superior+Po rtuguesas/

Diogo, S., Carvalho, T., \& Amaral, A. (2015). Institutionalism and organizational change. In J. Huisman, H. de Boer, D. D. Dill, \& M. Souto-Otero (Eds.), The Palgrave international handbook of higher education policy and governance (pp. 114-131). London: Palgrave Macmillan UK.

Finnish Higher Education Evaluation Council, FINHEEC. (2012). Evaluation of the Bologna process implementation in Finland. Helsinki: FINHEEC Publications.

Guri-Rosenblit, S., Šebková, H., \& Teichler, U. (2007). Massification and diversity of higher education systems: Interplay of complex dimensions. Higher Education Policy, 20(4), 373-389.

Haas, P. M. (1992). Introduction: Epistemic communities and international policy coordination. International Organization, 46(01), 1-35.

Harwood, J. (2010). Understanding academic drift: On the institutional dynamics of higher technical and professional education. Minerva, 48(4), 413-427.

Heggen, K., Karseth, B., \& Kyvik, S. (2010). The relevance of research for the improvement of education and professional practice. In S. Kyvik \& B. Lepori (Eds.), The research Mission of higher education institutions outside the university sector (pp. 45-61). Dordrecht: Springer.

Horta, H., Huisman, J., \& Heitor, M. (2008). Does competitive research funding encourage diversity in higher education? Science and Public Policy, 35(3), 146-158.

Huisman, J., \& van Vught, F. (2009). Diversity in European higher education: Historical trends and current policies. In F. van Vught (Ed.), Mapping the higher education landscape (pp. 17-37). Dordrecht: Springer.

Hölttä, S., \& Malkki, P. (2000). Response of finnish higher education institutions to the national information society programme. Higher Education Policy, 13(3), 231-243.

Jongbloed, B. (2010). The regional relevance of research in universities of applied sciences. In S. Kyvik \& B. Lepori (Eds.), The research Mission of higher education institutions outside the university sector (pp. 25-44). Dordrecht: Springer. 
Kallo, J. (2009). OECD education policy. A comparative and historical study focusing on the thematic reviews of tertiary education. $\mathrm{PhD}$ thesis, Helsinki.

Kauko, J., \& Diogo, S. (2012). Comparing higher education reforms in Finland and Portugal. Higher Education Management and Policy, 23(3), 1-20.

Kyvik, S. (2009). The dynamics of change in higher education: Expansion and contraction in an organisational field. Dordrecht: Springer.

Kyvik, S., \& Lepori, B. (2010). Research in higher education institutions outside the university sector. In S. Kyvik \& B. Lepori (Eds.), The research mission of higher education institutions outside the university sector: Striving for differentiation (pp. 3-21). Dordrecht: Springer.

Kyvik, S., \& Skodvin, O. (2003). Research in the non-university higher education sector-tensions and dilemmas. Higher Education, 45(2), 203-222.

Law 62/2007 (10th September). The legal framework of higher education institutions. Portuguese Government. Available at http://www.a3es.pt/sites/default/files/Law\%2062-2007.pdf

Law 932/2014. Universities of Applied Sciences Act. Finnish Government. Available at https:// www.finlex.fi/fi/laki/kaannokset/2014/en20140932.pdf

Lepori, B., \& Kyvik, S. (2010). The research mission of universities of applied sciences and the future configuration of higher education systems in Europe. Higher Education Policy, 23(3), 295-316.

Lundvall, B. (2007). National innovation systems-Analytical concept and development tool. Industry and Innovation, 14(1), 95-119.

Machado, M. d. L., Ferreira, J. B., Santiago, R., \& Taylor, J. S. (2008). Reframing the nonuniversity sector in Europe: Convergence or diversity? In J. S. Taylor, J. B. Ferreira, M. d. L. Machado, \& R. Santiago (Eds.), Non-university higher education in Europe (pp. 245-260). Dordrecht: Springer.

Magalhães, A. M. (2004). A identidade do ensino superior: política, conhecimento e educação numa época de transição. Lisboa: Fundação Calouste Gulbenkian.

March, J. G., \& Olsen, J. P. (1983). The new institutionalism: Organizational factors in political life. American Political Science Review, 78(3), 734-749.

Marginson, S., \& Wende, v. d. M. (2007). Globalisation and higher education (Education working paper, no. 8). Paris: OECD - Organisation for Economic Cooperation and Development.

Martens, K., \& Wolf, K. (2009). Boomerangs and Trojan horses: The unintended consequences of internationalising education policy through the EU and the OECD. In A. Amaral, G. Neave, C. Musselin, \& P. Maassen (Eds.), European integration and the governance of higher education and research (Vol. 26, pp. 81-107). Dordrecht: Springer.

Meek, V. L., Goedegebuure, L., Kivinen, O., \& Rinne, R. (Eds.). (1996). The mockers and mocked: Comparative perspectives on differentiation, convergence and diversity in higher education. New York: International Association of Universities and Elsevier Science Ltd.

Morphew, C., \& Huisman, J. (2002). Using institutional theory to reframe research on academic drift. Higher Education in Europe, 27(4), 491-506.

OECD. (2007). OECD reviews for tertiary education. Portugal. Paris: OECD Publishing.

OECD. (2009). OECD reviews for tertiary education. Finland. Paris: OECD Publishing.

OKM. (2016). Ministry of Education and Culture (OPETUS-JA KULTTUURIMINISTERIÖ). http://www.minedu.fi/OPM/Koulutus/?lang=en

Official Statistics of Finland, OSF. (2018). Education. Universities of applied sciences. Helsinki: Statistics Finland. Available at http://www.stat.fi/til/akop/2016/ akop_2016_2017-04-19_tau_001_en.html.

Official Statistics of Finland, OSF. (2016). Students and qualifications of educational institutions. Helsinki: Statistics Finland. Available at: http://www.stat.fi/til/opiskt/2016/ opiskt_2016_2017-11-29_tie_001_en.html.

Oliver, C. (1991). Strategic responses to institutional processes. Academy of Management Review, 16(1), 145-179.

Pedrosa, J., Teixeira, P., Moreira, M., \& Santoalha, A. (2017). Educação Superior em Portugal. Uma Nova Perspectiva. Lisboa: Fundação Calouste Gulbenkian. 
Rinne, R. (2004). Searching for the rainbow: Changing the course of Finnish higher education. In I. Fägerlind \& G. Strömqvist (Eds.), Reforming higher education in the Nordic countries Studies of change in Denmark, Finland, Iceland, Norway and Sweden (pp. 89-136). Paris: International Institute for Educational Planning - UNESCO.

Saarinen, T. (2008). Persuasive presuppositions in OECD and EU higher education policy documents. Discourse Studies, 10(3), 341-359. https://doi.org/10.1177/1461445608089915.

Sahlberg, P. (2011). Finnish lessons: What can the world learn from educational change in Finland. New York and London: Teachers College Press.

Santiago, R., Carvalho, T., \& Relva, R. (2008). Research and the universities' image. European Journal of Education, 43(4), 495-512.

Scott, P. (1995). The meanings of mass higher education. Buckingham: SRHE and Open University Press.

Teichler, U. (2014). Diversity and diversification of higher education: Trends, challenges and policies. Educational Studies, Higher School of Economics, issue, 1, 14-38.

Trow, M. (1995). Diversity in higher education in the United States of America. Paper presented at the CVCP Seminar on Diversity in Higher Education, London, 14, 15 September.

UNDP, U. N. (2015). The 2015 human development report. Retrieved from New York, USA: http:// hdr.undp.org/sites/default/files/2015_human_development_report.pdf

Van Vught, F. (2008). Mission diversity and reputation in higher education. Higher Education Policy, 21(2), 151-174.

Välimaa, J. (2004). Nationalisation, localisation and globalisation in Finnish higher education. Higher Education, 48(1), 27-54.

Välimaa, J., \& Neuvonen-Rauhala, M.-L. (2008). Polytechnics in Finnish higher education. In J. Taylor, J. Ferreira, M. Machado, \& R. Santiago (Eds.), Non-university higher education in Europe (pp. 77-98). Dordrecht: Springer.

Wit, K. (2007). On Unity and Diversity; the EU, Bologna and higher education. In J. Enders \& F. A. van Vught (Eds.), Towards a cartography of higher education policy change - a festschrift in honour of guy Neave (pp. 245-254). Enschede: CHEPS, University of Twente.

Witte, J., van der Wende, M., \& Huisman, J. (2008). Blurring boundaries: How the Bologna process changes the relationship between university and non-university higher education in Germany, the Netherlands and France. Studies in Higher Education, 33, 217-231.

Open Access This chapter is licensed under the terms of the Creative Commons Attribution 4.0 International License (http://creativecommons.org/licenses/by/4.0/), which permits use, sharing, adaptation, distribution and reproduction in any medium or format, as long as you give appropriate credit to the original author(s) and the source, provide a link to the Creative Commons license and indicate if changes were made.

The images or other third party material in this chapter are included in the chapter's Creative Commons license, unless indicated otherwise in a credit line to the material. If material is not included in the chapter's Creative Commons license and your intended use is not permitted by statutory regulation or exceeds the permitted use, you will need to obtain permission directly from the copyright holder.

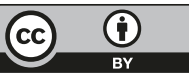

